\title{
MOTIVASI BONUS PLAN DALAM FRAUDELENT FINANCIAL STATEMENT
}

\author{
MF. Arrozi Adhikara, Anelis Haryanto \\ Fakultas Ekonomi dan Bisnis Universitas Esa Unggul \\ Jalan Arjuna Utara No 9 Kebon Jeruk Jakarta 11510 \\ arrozi@esaunggul.ac.id
}

\begin{abstract}
This study to examine the elements of fraud in the Pentagon fraud theory indetecting fraudulent financial statements. Fraud pentagon is proxied by six variables consisting of two elements of pressure (financial target and external pressure), one variable from element opportunity (ineffective monitoring), one variable from element rationalization (change in auditor), one variable from capability element (change in directors)), and one variable from the arrogance element (number of CEO's pictures) hypothesized to affect fraudulent financial statements. F-Score is used to determine the fraudulent financial statement with bonus plan based earnings management as an intervening variable. This study with a sample of 35 companies was selected using a purposive sampling method from delisting companies in the Indonesia Stock Exchange in 20092016. Hypothesis testing uses a path analysis to test the Effects of Pressure, Opportunity, Rationalization, Competence, and Arrogance Against the Fraudulent Financial Statement with Earning Management Based on Bonus Plans as Intervening Variables on Companies Delisting on the Indonesia Stock Exchange 2009-2016.

The results showed that ROA, DER, RKI had a positive effect on earnings management. While earnings management has a negative effect on fraudulent financial statements. DER and CEO have a negative effect on fraudulent financial statements and CPA has a positive effect on fraudulent financial statements.
\end{abstract}

Keywords : fraudulent financial statement, opportunity, rationalization

\begin{abstract}
Abstrak
Penelitian ini untuk menguji unsur-unsur penipuan dalam teori penipuan Pentagon mengidentifikasi laporan keuangan penipuan. Pentagon penipuan diproksikan oleh enam variabel yang terdiri dari dua elemen tekanan (target keuangan dan tekanan eksternal), satu variabel dari elemen peluang (pemantauan tidak efektif), satu variabel dari elemen rasionalisasi (perubahan auditor), satu variabel dari elemen kemampuan (perubahan dalam sutradara), dan satu variabel dari elemen arogansi (jumlah gambar CEO) dihipotesiskan mempengaruhi laporan keuangan yang curang. F-Score digunakan untuk menentukan laporan keuangan yang curang dengan manajemen bonus berdasarkan rencana bonus sebagai variabel intervening. Penelitian ini dengan sampel 35 perusahaan yang dipilih menggunakan metode purposive sampling dari perusahaan delisting di Bursa Efek Indonesia pada tahun 20092016. Pengujian hipotesis menggunakan analisis jalur untuk menguji Pengaruh Tekanan, Peluang, Rasionalisasi, Kompetensi, dan Keangkuhan Terhadap Penipuan. Laporan Keuangan dengan Manajemen Pendapatan Berdasarkan Rencana Bonus sebagai Variabel Intervening pada Perusahaan yang Delisting di Bursa Efek Indonesia 2009-2016. Hasil penelitian menunjukkan bahwa ROA, DER, RKI memiliki efek positif pada manajemen laba. Sedangkan manajemen laba berpengaruh negatif terhadap laporan keuangan yang curang. DER dan CEO memiliki efek negatif pada laporan keuangan yang curang dan CPA memiliki efek positif pada laporan keuangan yang curang.
\end{abstract}

Kata kunci: penipuan laporan keuangan, peluang, rasionalisasi 


\section{Pendahuluan}

Kecurangan akuntansi dalam laporan keuangan merupakan tindakan akuntansi kreatif, moral hazard, dan oportunis. Timbulnya akuntansi kreatif karena perusahaan harus memperoleh laba. Sehingga, manajer membuat perilaku oportunis dalam bentuk kebijakan akuntansi, manajemen laba, income smoothing, serta fraud. Akuntansi memberi peluang untuk memilih alternatif metode akuntansi dalam standar. Akuntan memanfaatkan peluang 'loophole' dengan cara merekayasa transaksi dalam laporan keuangan (fraudulent financial statement) karena oportunis keuntungan, tekanan, kesempatan, dan rasionalisasi (Arrozi, 2011; Arrozi, 2012; Arrozi, 2018). Sehingga, laporan keuangan mengandung informasi yang tidak wajar, tidak relevan, dan tidak reliable yang akan menyesatkan user dalam pengambilan keputusan (Arrozi et al,, 2014; Arrozi et al, 2016; Arrozi et al,, 2017).

Isu fraudulent financial statement menjadi perhatian karena runtuhnya perusahaan terkemuka Toshiba, KAP Arthur Andersen, PT Ades, PT Kimia Farma, dan PT Waskita Karya (Arrozi, 2018). Perusahaan melakukan penyembunyian informasi yang relevan dan wajar karena factor persaingan bisnis, motivasi disclosure laporan keuangan terlihat wajar dan menarik perhatian user, sehingga perusahaan melakukan manipulasi pencatatan, penghilangan dokumen, mark-up (Tessa dkk., 2016) serta manajemen laba (Arrozi, 2018).

Fraud meliputi sebuah ketidakberesan dan tindakan ilegal yang dikarakteristikan dengan penipuan yang disengaja (Auditor of Public Accounts, 2011), dan terjadi karena tindakan yang disengaja dari pelaku, dan tindakan itu tidak dapat dibenarkan. Fraud adalah sebuah tindakan disengaja dalam sebuah kecurangan material dalam laporan keuangan yang menjadi subjek audit (AICPA, 2002). Perusahaan hanya dapat meminimalisasi fraud, karena faktor penyebab fraud berbagai macam dan kompleks (Tuanakotta. 2012). Sehingga dapat mengerti perilaku fraud dengan memahami siapa fraudsters dan mengapa fraud dilakukan (Ruankaew, 2013).
Studi ini mengembangkan teori fraud pentagon dan teori akuntansi positif bahwa dalam fraudulent financial statement terdapat unsur motivasi kejahatan dalam laporan keuangan (Dorminey, et. al., 2012), seperti perencanaan bonus yang diinginkan oleh manajer perusahaan (Arrozi, 2012). Penguasaan informasi perusahaan terkait laporan keuangan menjadi sasaran utama. Fraud terjadi melalui perceived pressure, perceived opportunity, rationalization, competence, dan arrogance (Skousen, et., al, 2009, Howarth, 2012). Sedangkan, perencanaan bonus sebagai intervensi manajemen terhadap pelaporan keuangan merupakan upaya keuntungan pribadi manajer dan stakeholder mengambil keputusan sesuai harapan manajer (Dechow et al., 2009).

Hal tersebut diatas menimbulkan conflict of interest antara prinsipal dan agen. Sehingga manajemen mengalami tekanan untuk meningkatkan kinerja sebagai pembenaran dan memperoleh kesempatan dalam peningkatan laba karena memperoleh akses luas terhadap informasi perusahaan (Sihombing dkk., 2014). Fraud terjadi karena sikap percaya diri, arogansi serta ahli dalam memahami pengendalian internal.

Motivasi penelitian adalah; Pertama, perilaku fraud belum terdapat kajian empiris dalam melibatkan motif manajemen laba pada perspektif perilaku moral hazard. Studi ini mengkaji fraudulent financial statement dengan mengembangkan konstruksi Fraud Pentagon Theory dengan Positive Accounting Theory pada motivasi bonus plan. Kedua, earning management dilakukan agen terhadap penggunaan dasar pembukuan akrual yang menuntut keahlian agen untuk memanfaatkan celah dalam pelaporan keuangan, sehingga dapat memperlihatkan kinerja yang baik dalam laporan keuangan. Ketiga, earning management mudah dilakukan pada perusahaan manufaktur berskala besar karena memiliki transaksi yang banyak, kompleks, sistem pengawasan yang luas sehingga perilaku moral hazard sulit untuk terdeteksi.

Tujuan penelitian yang dicapai adalah memperoleh bukti empiris untuk konstruksi model fraudulent financial statement yang sesuai untuk kajian faktor internal dan eksternal tentang agen melakukan fraud pada 
lingkungan budaya transaksional dengan motivasi bonus plan di perusahaan yang mengalami financial distress.

Kontribusi penelitian ini adalah penguatan etis atas sikap akuntan perusahaan dalam proses pengakuan, penilaian, pengukuran, serta disclosure laporan keuangan dalam memberikan judgement dalam estimasi Standar Akuntansi Keuangan. Sehingga, mampu mengeliminasi celah bagi akuntan dalam mencari loophole untuk bertindak fraud. Implikasinya adalah kualitas informasi laporan keuangan dalam reliabilitas dan relevansi akan meningkat dan mengurangi asimetri informasi.

\section{Tinjauan Pustaka \\ Fraud Theory}

Fraud Pentagon Theory (Howarthm 2012) merupakan perluasan dari teori fraud triangle. Komponen teori fraud pentagon adalah sebagai berikut, yaitu; (1) Arogansi. Arogansi menunjukkan superioritas kepercayaan diri yang tinggi sehingga pengendalian internal tidak berlaku untuk dirinya. Pelaku fraud berpikir bebas tanpa takut terkena sanksi. (2) Kompetensi. Kompetensi merupakan keahlian yang bisa terjadi fraud karena kemampuan untuk melakukan terjadinya hal tersebut. Kompetensi yang dimiliki seseorang dalam perusahaan akan mempengaruhi bagaimana seseorang tersebut melakukan fraud. Wolfe dan Hermansn (2004) mengemukakan bahwa perubahan direksi mampu menyebabkan stress period yang berdampak pada semakin terbukanya peluang untuk melakukan fraud. Pergantian direksi dapat menjadi suatu upaya perusahaan untuk memperbaiki kinerja direksi sebelumnya dengan melakukan perekrutan direksi baru yang dianggap lebih berkompeten. (3) Peluang. Fraud terjadi karena peluang untuk melakukannya jika berisiko kecil untuk dideteksi dan diketahui. Peluang terjadi karena adanya persepsi lemahnya pengendalian (Dorminey, 2012). Fraud bisa dilakukan oleh orang yang memiliki posisi penting dalam perusahaan dan memungkinka melakukan fraud. (4) Tekanan. Fraud dilakukan karena tekanan dan masalah keuangan yang tidak dapat dibagikan pada orang lain. Tekanan melibatkan sebuah financial need, meskipun tekanan non-financial juga bisa memotivasi timbulnya fraud. Seperti, kebutuhan hasil laporan yang lebih baik diatas factual, frustasi kerja, serta tantangan untuk mengacaukan system (Albrecht, et., al., 2008; Dorminey, 2012). (5) Rasionalisasi. Rasionalisasi merupakan pembenaran penyembunyian fraud, dan mencari alasan untuk menutupi fraud yang telah dilakukannya. Rasionalisasi terjadi ketika seorang membenarkan mengapa mereka melakukan fraud dan membenarkan apa yang merela lakukan menurut hukum itu salah. (Auditor of Public Accounts, 2011).

\section{Positive Accounting Theory}

Teori akuntansi positif memberikan penjelasan dengan menggunakan pengetahuan dan penggunaan akuntansi yang sesuai untuk menjelaskan dan memprediksi praktik-praktik akuntansi. Prediksi teori akuntansi positif diformulasikan oleh Watts dan Zimmerman (1986) dalam bentuk oportunistik yang dibuatkan dalam tiga hipotesis, yaitu: (1) Bonus Plan Hipotesis, yaitu dalam hal lain dengan keadaan tetap, manajer yang merencanakan bonus akan memilih kebijakan akuntansi yang melaporkan laba masa depan ke masa kini. (2) Debt Covenant Hipothesis, yaitu dalam hal lain dengan keadaan tetap, dengan kebijakan akuntansi yang melakukan pelanggaran dengan kesepakatan utang, maka akan memilih kebijakan akuntansi yang melaporkan laba masa depan ke masa kini. (3) Political Cost, Cost Politic, yaitu dalam hal lain dengan keadaan tetap, biaya politik yang semakin besar ditanggung perusahaan, manajer memilih kebijakan akuntansi yang melaporkan laba masa kini menuju masa depan.

\section{Manajemen Laba}

Dechow et al. (2009) menunjukkan bahwa manajemen laba merupakan intervensi manajemen dalam proses pelaporan keuangan eksternal dan atas intervensi manajemen. Dasar proses ini adalah Standar Akuntansi Keuangan memberi fleksibellitas untuk memilih kebijakan akuntansi kepada manajemen. Tujuannya pada kepentingan pribadi dan manajemen. Sehingga, user mengambil keputusan sesuai harapan manajer.

Manajemen laba dibuat perusahaan karena motivasi sebagai berikut (Scott, 2015), (a) Motivasi bonus. Manajer mengatur laba 
untuk memaksimalkan bonus; (b) Motivasi kontrak. Manajer menaikkan laba bersih untuk mengurangi terjadinya technical default, (c) Motivasi politik. Motivasi perusahaan yang terlibat dalam aktivitas menyangkut hajat hidup orang; (d) Motivasi pajak. Manajemen menghindari pembayaran pajak melalui pelaporan laba bersih minimal; (e) Pergantian CEO. CEO mendekati masa pensiun akan meningkatkan bonusnya, dan CEO yang baru menunjukkan kesalahan dari CEO sebelumnya; (f) Initial Public Offering. Manajer melakukan manajemen laba untuk memperoleh respon positif sebagai sinyal supaya harga saham menjadi tinggi. (g) Motivasi capital market. Manajemen laba dilakukan dengan pola taking a bath, income minimization, income maximization, dan income smoothing.

Tindakan

manajemen laba

merupakan dasar terjadinya fraudulent financial statement (Skousen et al. 2009). Tindakan ini memunculkan kasus skandal pelaporan akuntansi, yaitu Enron, World Com, dan di Indonesia melibatkan PT. Ades dan PT Kimia Farma Tbk yang berawal dari terdeteksi adanya manipulasi laporan keuangan. Hasil ini menunjukkan indikasi hubungan manajemen laba dengan fraudulent financial statement.

\section{Fraudelent Financial Statement}

Fraudulent financial statement adalah salah saji yang disengaja untuk menipu user laporan keuangan melalui melebihsajikan aktiva dan laba; mengabaikan kewajiban dan beban; merendahsajikan laba; meninggikan nilai aset dan pengakuan pendapatan; serta merendahkan nilai liabilitas dan pembebanan ongkos operasional dan biaya produksi (Arens, et. al., 2008; Priantara, 2013). Fraudulent financial statement merupakan perbuatan sengaja atas perubahan data akuntansi untuk kepentingan pribadi dari manajemen melalui penyajian yang tidak memadai atas informasi keuangan yang berstandar. Hal ini akan menghasilkan keputusan yang salah dari pihak stakeholders yang berkepentingan terhadap laporan keuangan.

Fraudulent financial statement berkaitan dengan aktivitas-aktivitas sebagai berikut: manipulasi dari catatan keuangan, dokumen pendukung atau transaksi bisnis; kesalahan pencatatan material yang disengaja dari kejadian dan transaksi yang merupakan sumber informasi pembuatan laporan keuangan; kesalahan yang disengaja pada prinsip, kebijakan, dan prosedur akuntansi untuk mengukur, mengakui, menilai, dan mengungkapkan transaksi bisnis; serta penghilangan secara sengaja dari penyajian pengungkapan yang tidak memadai berkaitan dengan standar, prinsip, dan praktek akuntansi pada informasi keuangan (Rezaee, 2002).

\section{Hasil Studi Terdahulu}

Lou dan Wang menggunakan sebuah model logistik sederhana berdasarkan contoh faktor risiko kecurangan ISA 240 dan SAS 99 untuk mengestimasi adanya kecurangan laporan keuangan. Hasil penelitian menunjukkan kecurangan laporan keuangan berhubungan dengan kondisi tekanan keuangan dari perusahaan atau supervisor perusahaan, rasio tertinggi dari transaksi yang kompleks dalam perusahaan, integritas manajemen, dan penurunan hubungan perusahaan dengan auditornya (Lou et al., 2009). Dalnial et al., (2014) menghasilkan penelitian bahwa analisis laporan keuangan dapat mendeteksi kecurangan pelaporan keuangan. Sehingga, memberi hasil bahwa leverage, capital turnover, dan aset composition sebagai variabel yang signifikan dalam mendeteksi kecurangan laporan keuangan.

Penelitian Sihombing dkk, (2014) menghasilkan temuan bahwa financial stability, extenal pressure, nature of industry, dan rationalization berpengaruh terhadap financial statement fraud. Penelitian ini tidak membuktikan financial target, ineffective monitoring, change in auditor, dan capability tidak memiliki pengaruh terhadap financial statement fraud. Penelitian Tessa dkk. (2016) menghasilkan bukti terjadinya fraudulent financial statement, adalah financial stability, external pressure, dan frequent number of CEO's picture. Variabel ini sebagai representasi elemen Crowe's fraud pentagon theory, yaitu pressure dan arogansi.

Penelitian Aprilia (2017) menunjukkan bahwa stabilitas keuangan berpengaruh 
terhadap kecurangan laporan keuangan. Sedangkan, variabel politisi CEO, frekuensi kemunculan gambar CEO, kebijakan hutangpiutang yang meragukan, efektifitas pengawasan, pergantian auditor internal, tekanan eksternal, kepemilikan manajerial, pergantian kebijakan akuntansi, serta opini audit tidak berpengaruh terhadap kecurangan laporan keuangan. Creative accounting timbul karena perusahaan harus berada dalam posisi laba, sehingga manajemen membuat tindakan oportunistik yaitu melalui tindakan accounting policy, earning management, income smoothing, manipulasi laporan keuangan, serta fraud akuntansi. Creative accounting menyalahi prosedur atau undang-undang yang berlaku melalui "LOOPHOLE" dalam aturan itu sendiri (Arrozi, 2011).

Hasil penelitian Ratmono (2014) memberi dukungan teori fraud triangle dalam menjelaskan fenomena kecurangan laporan keuangan. Terjadi hubungan positif tekanan dan rasionalisasi terhadap kecurangan laporan keuangan. Kesempatan tidak didukung sebagai determinankecurangan laporan keuangan.

Penelitian Marliani dan Jogi (2015) menunjukkan bahwa pencurian kas terjadi karena dipicu oleh faktor tekanan, kesempatan, dan rasionalisasi. Faktor terbesar dukungan dari tekanan, kesempatan, dan rasionalisasi berpengaruh positif terhadap pencurian kas dengan tingkat persentase terbesar adalah 25,8\%; 19,3\%; 24,2\%. Hasil penelitian Albrecht (2015) menjelaskan bahwa rasionalisasi terjadi karena pelaku merasa dirinya melakukan sesuatu yang sudah sewajarnya bukan sebagai tindak criminal. Sehingga, rasionalisasi diperlukan pelaku fraud untuk menciptakan persepsi bahwa mereka jujur tetapi korban kondisi. Sedangkan, tekanan dapat memotivasi seseorang untuk melakukan tindakan pencurian kas dan sebagai faktor pemicu terjadinya pencurian kas.

\section{Pengembangan Hipotesis}

Berdasarkan tinjauan teori terkait dan hubungan antar variabel dalam pnelitian ini, dapat dirumuskan hipotesis sebagai berikut:

$\mathrm{H}_{1 \mathrm{a}}$ : ROA berpengaruh positif terhadap Earning Management
$\mathrm{H}_{1 \mathrm{~b}}$ : DER berpengaruh positif terhadap Earning Management

$\mathrm{H}_{2}$ : RKI berpengaruh positif terhadap Earning Management

$\mathrm{H}_{3}$ : CPA berpengaruh positif terhadap Earning Management

$\mathrm{H}_{4}$ : DCHANGE berpengaruh positif Terhadap Earning Management

$\mathrm{H}_{5}$ : CEO berpengaruh positif terhadap Earning Management

$\mathrm{H}_{6}$ : Pressure, Opportunity, Rationalization, Competence dan Arrogance berpengaruh positif terhadap Earning Management Secara Simultan.

$\mathrm{H}_{7}$ : Earning Management berpengaruh positif terhadap Fraudulent Financial Statement

$\mathrm{H}_{8} \mathrm{a}$ : ROA berpengaruh positif terhadap Fraudulent Financial Statement

$\mathrm{H}_{8 \mathrm{~b}}$ : DER berpengaruh positif terhadap Fraudulent Financial Statement

$\mathrm{H}_{9} \quad$ : RKI berpengaruh positif terhadap Fraudulent Financial Statement

$\mathrm{H}_{10}$ : CPA berpengaruh positif terhadap Fraudulent Financial Statement

$\mathrm{H}_{11}$ : DCHANGE berpengaruh positif Terhadap Fraudulent Financial Statement

$\mathrm{H}_{12}$ : CEO berpengaruh positif terhadap Fraudulent Financial Statement

$\mathrm{H}_{13}$ : Pressure, Opportunity, Rationalization, Competence, dan Arrogance berpengaruh positif terhadap Fraudulent Financial Statement Secara Simultan.

\section{Metode Penelitian}

Rancangan penelitian berbentuk pengujian hipotesis dengan tipe kausalitas ekspalanatoris yang bertujuan untuk menguji hubungan kausal secara simultan antar variabel tekanan, rasional, kesempatan, kompetensi, arogansi, moral hazard, dan fraudulent financial statement. Metode pengumpulan data adalah dokumentasi dari survey kepustakaan. Jenis data berbentuk sekunder berupa data obyek dari perusahaan manufaktur di bursa efek Indonesia. Dimensi waktu adalah cross section. Unit analisis adalah perusahaan yang mengalami financial distress. Penelitian ini menggunakan alat uji path analysis. 
Populasi, Besar Sampel, dan Teknik Pengambilan Sampel.

Populasi dalam penelitian ini adalah perusahaan delisting di Bursa Efek Indonesia (BEI) periode 2009-2017. Alasan delisting di Bursa Efek Indonesia karena keterdugaan fraud secara mandatory. Jumlah populasi adalah sebesar 70 .

Teknik pengambilan sampel adalah sampel jenuh. Artinya, sampel dipilih dengan menggunakan jumlah sampel yang sama dengan populasi dengan jumlah 70 .
Variabel Penelitian. Variabel penelitian ini dikelompokkan sebagai berikut:

1. Variabel eksogen atau independen dalam penelitian ini merupakan variabel yang dikembangkan dari fraud pentagon yang terdiri dari; yaitu opportunit (X1), rasionalisasi $(\mathrm{X} 2)$, pressure $(\mathrm{X} 3)$, kompeten (X4), dan arogansi (X5).

2. Variabel endogen atau intervening adalah earning management (Z).

3. Variabel endogen atau variabel dependen, yaitu fraudelent financial statement $(\mathrm{Y})$.

\section{Definisi Operasional Variabel.}

Tabel 1

Definisi Operasional Variabel

\begin{tabular}{|c|c|c|c|c|}
\hline $\mathbf{N}$ & Variable & Definition & Measurement & Scale \\
\hline 1 & $\begin{array}{l}\text { fraudelent } \\
\text { financial } \\
\text { statement }\end{array}$ & $\begin{array}{l}\text { Agents conduct financial statement } \\
\text { disclosures that are not appropriate for their } \\
\text { own needs, other parties, and other groups } \\
\text { that will harm certain parties. }\end{array}$ & $\begin{array}{l}\text { Fraud score model (Dechow et } \\
\text { al., 2009). } \\
\text { F-Score = Accrual Quality }+ \\
\text { Financial Performance }\end{array}$ & Rasio \\
\hline 2 & $\begin{array}{l}\text { Earning } \\
\text { Management }\end{array}$ & $\begin{array}{l}\text { selection of accounting policies by } \\
\text { agent to achieve efficiency and } \\
\text { opportunistic goals and motivation in an } \\
\text { effort to maximize profits for himself. }\end{array}$ & $\begin{array}{l}\text { Discretionary accruals } \\
\text { Modified Jones Model } \\
\text { Dechow (1995). DACCit }= \\
\text { TACit/Ait- NDACCit }\end{array}$ & Rasio \\
\hline 3 & Pressure & $\begin{array}{l}\text { The pressure exerted by the board of } \\
\text { directors, executives, officers, investors, } \\
\text { or creditor. }\end{array}$ & $\begin{array}{l}\text { 1. Financial target } \\
\text { ROA = NI/TA } \\
\text { 2. External pressure, } \\
\text { DER = liability/equity }\end{array}$ & Rasio \\
\hline 4 & Opportunity & $\begin{array}{l}\text { The condition of the company does not } \\
\text { have a system effective internal supervision } \\
\text { in monitoring company performance. }\end{array}$ & $\begin{array}{l}\text { Ineffective monitoring Was } \\
\text { measurement from independent } \\
\text { commisarist ratio (RKI) }\end{array}$ & Rasio \\
\hline 5 & Rasionalisasi & $\begin{array}{l}\text { auditor change to eliminate trace of fraud } \\
\text { trail found by previous auditors. }\end{array}$ & $\begin{array}{l}\text { change in Auditor ( } \triangle \mathrm{CPA}) \text { that } \\
\text { is auditor change in the } \\
\text { observation period. If there is a } \\
\text { replacement given the number } 1 \text {, } \\
\text { and if there is no substitution }\end{array}$ & $\begin{array}{l}\text { Nominal } \\
\text { Dummy }\end{array}$ \\
\hline 6 & Competence & $\begin{array}{l}\text { The company improves the performance of } \\
\text { directors previously by recruiting new, more } \\
\text { competent directors. . }\end{array}$ & $\begin{array}{l}\text { Change of Directors. There is a } \\
\text { change of directors given number } \\
1 \text {, and not changing directors given } \\
\text { numbers } 0\end{array}$ & $\begin{array}{l}\text { Nominal } \\
\text { Dummy }\end{array}$ \\
\hline 7 & Arrogance & $\begin{array}{l}\text { The number of portraits of CEOs on display } \\
\text { in the company's annual report }\end{array}$ & Number of CEO's picture. & Nominal \\
\hline
\end{tabular}

Model penelitian dalam fraudulent financial statement terdapat pada gambar 3.1 sebagai berikut : 


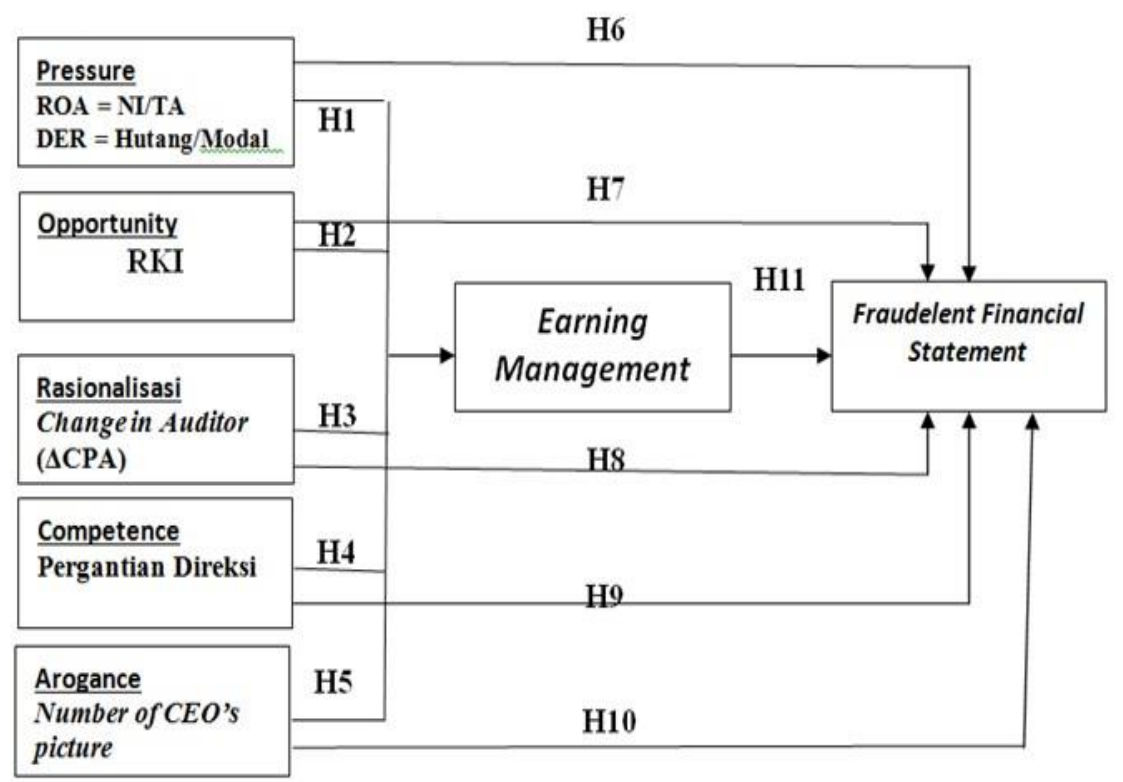

Gambar 3.1. Model Penelitian

Data akan dianalisis dengan menggunakan Path menggunakan model persamaan path sehingga Analysis. Hasil analisis digunakan dalam diperoleh persamaan regresi atau rumus analisis pengujian hipotesis 1 sampai dengan 11 jalur ditunjukkan dalam persamaan sebagai melalui analisis path (jalur) dan analisis factor. berikut:

Untuk menguji model yang diusulkan, peneliti

$$
\begin{aligned}
& \text { EM = Y1 ROA + Y2 DER + Y3 RKI + Y4 CPA + Y5 PDIR + y6 CEO } \\
& \text { FRAUD = Y7 EM } \\
& \text { FRAUD = Y8 ROA + Y9 DER + Y10 RKI + Y11 CPA + Y12 PDIR + Y13 CEO }
\end{aligned}
$$

\section{Hasil dan Pembahasan}

Statistik deskriptif digunakan untuk memberikan deskripsi suatu data yang dilihat dari minimum, maksimum, rata-rata (mean) dan standar deviasi (standard deviation). Deskriptif dari masing-masing penelitian diperoleh sebagai berikut:

Tabel 2

Descriptive Statistics

\begin{tabular}{|l|r|r|r|r|r|}
\hline & $\mathrm{N}$ & \multicolumn{1}{|c|}{ Minimum } & Maximum & \multicolumn{1}{c|}{ Mean } & Std. Deviation \\
\hline ROA & 70 & -19.87000 & 6.11000 & -.0556286 & 4.30403298 \\
DER & 70 & -4.20000 & 25.60000 & 1.5871429 & 4.92457344 \\
RKI & 70 & .00000 & .80000 & .3871429 & .14258629 \\
CPA & 70 & 0 & 1 & .09 & .282 \\
DCHANGE & 70 & 0 & 1 & .20 & .403 \\
CEO & 70 & 0 & 4 & .69 & 1.198 \\
EM & 70 & -.134649 & .188914 & .01370909 & .082909074 \\
FDL & 70 & -3.44000 & 3846.32000 & 270.5342857 & 825.87639318 \\
Valid N (listwise) & 70 & & & & \\
\hline
\end{tabular}




\section{Pengujian Hipotesis}

Hasil pengujian hipotesis terdapat pada tabel 2 dan 3 sebagai berikut:

Tabel 3

Pengujian Jalur 1

\begin{tabular}{|c|c|c|c|c|c|c|c|}
\hline \multirow{2}{*}{\multicolumn{2}{|c|}{ Model }} & \multicolumn{2}{|c|}{$\begin{array}{l}\text { Unstandardized } \\
\text { Coefficients }\end{array}$} & $\begin{array}{c}\text { Standardized } \\
\text { Coefficients }\end{array}$ & \multirow[t]{2}{*}{$\mathrm{t}$} & \multirow[t]{2}{*}{ Sig. } & \multirow[t]{2}{*}{ Hipotesis } \\
\hline & & B & $\begin{array}{l}\text { Std. } \\
\text { Error }\end{array}$ & Beta & & & \\
\hline \multirow{7}{*}{1} & (Constant) & -.059 & .031 & & -1.913 & .060 & \\
\hline & ROA & .007 & .002 & .342 & 2.824 & .006 & H1a accepted \\
\hline & DER & .006 & .002 & .338 & 2.483 & .016 & H1b accepted \\
\hline & RKI & .177 & .070 & .304 & 2.514 & .015 & H2 accepted \\
\hline & CPA & -.057 & .039 & -.195 & -1.454 & .151 & H3 rejected \\
\hline & DCHANGE & -.025 & .027 & -.121 & -.916 & .363 & H4 rejected \\
\hline & CEO & .008 & .010 & .117 & .848 & .399 & H5 rejected \\
\hline
\end{tabular}

Tabel 4

Pengujian Jalur 2

\begin{tabular}{|c|c|c|c|c|c|c|}
\hline \multirow[t]{2}{*}{ Model } & \multicolumn{2}{|c|}{$\begin{array}{l}\text { Unstandardized } \\
\text { Coefficients }\end{array}$} & \multirow{2}{*}{$\begin{array}{c}\text { Standardized } \\
\text { Coefficients } \\
\text { Beta }\end{array}$} & \multirow[t]{2}{*}{$\mathrm{t}$} & \multirow[t]{2}{*}{ Sig. } & \multirow[t]{2}{*}{ Hipotesis } \\
\hline & $B$ & Std. Error & & & & \\
\hline (Constant) & 610.728 & 274.705 & & 2.223 & .030 & \\
\hline ROA & -10.207 & 20.738 & -.053 & -.492 & .624 & H8a rejected \\
\hline DER & -90.041 & 20.379 & -.537 & -4.418 & .000 & H8b accepted \\
\hline RKI & -470.638 & 625.665 & -.081 & -.752 & .455 & H9 rejected \\
\hline CPA & 1731.945 & 350.484 & .591 & 4.942 & .000 & H10 accepted \\
\hline DCHANGE & 58.706 & 240.701 & .029 & .244 & .808 & H11 rejected \\
\hline CEO & -256.438 & 84.517 & -.372 & -3.034 & .004 & H12 accepted \\
\hline
\end{tabular}

Tabel 5

Pengujian Jalur 3

\begin{tabular}{|c|c|c|c|c|c|c|c|}
\hline \multirow{2}{*}{\multicolumn{2}{|c|}{ Model }} & \multicolumn{2}{|c|}{$\begin{array}{l}\text { Unstandardized } \\
\text { Coefficients }\end{array}$} & \multirow{2}{*}{$\begin{array}{c}\text { Standardized } \\
\text { Coefficients } \\
\text { Beta }\end{array}$} & \multirow[t]{2}{*}{$\mathrm{t}$} & \multirow[t]{2}{*}{ Sig. } & \multirow[t]{2}{*}{ Hipotesis } \\
\hline & & $B$ & Std. Error & & & & \\
\hline \multirow{2}{*}{1} & (Constant) & 303.893 & 97.750 & & 3.109 & .003 & \\
\hline & EM & -2433.294 & 1171.382 & -.244 & -2.077 & .042 & H7 accepted \\
\hline
\end{tabular}

F test : 0.042

Coefficient Determinants : 0.046

H1a diterima sehingga dapat dikatakan bahwa ROA memiliki efek positif pada Manajemen Pendapatan.

ROA perusahaan yang tinggi akan mengatur laba operasional karena untuk mendapatkan rencana bonus yang dibuat oleh manajemen laba. ROA yang ditargetkan oleh perusahaan lebih tinggi, tingkat potensi perusahaan dalam mengelola pendapatan akan meningkat. Ini karena target keuangan yang harus dipenuhi oleh perusahaan memberikan tekanan pada manajer dalam melaksanakan kinerja mereka di mana mereka dituntut untuk selalu menjaga target keuangan perusahaan untuk mendapatkan rencana bonus. Hasil penelitian ini bertentangan dengan hasil 
penelitian dari Sihombing dan Rahardjo (2014), Tessa dan Harto (2016), dan juga penelitian Skousen et. al (2009) yang menyatakan bahwa Tekanan yang diukur dengan ROA tidak mempengaruhi laporan penipuan keuangan.

\section{H1b diterima sehingga dapat dikatakan bahwa DER memiliki efek positif pada Manajemen Pendapatan.}

Beberapa perusahaan memilih untuk menjadikan pinjaman sebagai sumber pendanaan operasional perusahaan. Jika tingkat kewajiban yang tinggi akan membuat manajemen laba perusahaan lebih sulit dalam membuat prediksi tentang masa depan perusahaan. Artinya, semakin besar hutang perusahaan, semakin ketat pengawasan yang dilakukan oleh kreditor, fleksibilitas manajemen untuk menutupi kewajiban yang tinggi akan dilakukan sehingga manajemen laba akan lebih tinggi. Hasil penelitian ini konsisten dengan Lou dan Wang (2009), Sihombing dan Rajardjo (2014), dan Tessa dan Harto (2016) di mana tekanan eksternal berpengaruh pada laporan keuangan yang curang. Namun, penelitian ini bertentangan dengan penelitian Oktarigusta (2016) yang menyatakan bahwa tekanan eksternal tidak mempengaruhi penipuan laporan keuangan.

\section{H2 diterima sehingga dapat dikatakan bahwa RKI memiliki efek positif terhadap Earning Management.}

Secara umum, keberadaan dewan komisaris independen akan memberikan sedikit jaminan pengawasan dalam suatu perusahaan. Namun, jumlah atau jumlah dewan komisaris independen belum memberikan jaminan untuk meningkatkan pengawasan operasional perusahaan. Ini disebabkan jika ada intervensi ke dewan komisaris independen, sehingga pengawasan di perusahaan menjadi tidak objektif. Hasil penelitian ini konsisten dengan penelitian yang dilakukan oleh Oktarigusta (2016) yang menyatakan bahwa efektivitas pengawasan diproksi dengan jumlah komisaris independen mempengaruhi kecurangan laporan keuangan.

H3 ditolak sehingga dapat dikatakan bahwa CPA tidak berpengaruh pada Manajemen Pendapatan.
Pergantian auditor dapat disebut sebagai jejak kerugian bagi perusahaan di mana manajemen laba dapat ditemukan oleh auditor lama. Namun berdasarkan hasil penelitian, adanya perubahan auditor tidak menjadikan justifikasi atas tindakan yang diambil (rasionalisasi) yang dapat dijadikan alasan bagi pelaku untuk mengambil tindakan manajemen laba. Selain itu, perubahan auditor lama menjadi auditor baru tidak dapat disimpulkan bahwa auditor pengganti tidak memiliki pengalaman dalam audit. Pergantian auditor juga tidak selalu terkait dengan jejak manajemen laba di suatu perusahaan tetapi masih ada hal-hal lain mengapa perubahan auditor dilakukan oleh klien mereka. Salah satu alasannya adalah bahwa perusahaan ingin mendapatkan auditor yang lebih efisien dan memiliki keahlian sesuai dengan industri perusahaan. Selain itu, tidak adanya kecocokan antara perusahaan internal dan auditor independen dalam menentukan metode akuntansi yang tepat dan tidak melanggar standar akuntansi saat ini juga dapat memicu pergantian auditor. Alasan lain adalah karena perusahaan ingin mematuhi peraturan yang berlaku di Indonesia, yaitu Peraturan Menteri Keuangan Republik Indonesia Nomor 17 / PMK.01 / 2008 pasal 3 ayat 1 yang menyatakan bahwa layanan audit publik dalam laporan keuangan suatu entitas harus dilakukan selama maksimal 6 tahun. untuk Kantor Akuntan Publik (KAP) dan 3 tahun berturut-turut untuk auditor yang sama untuk klien yang sama.

Hasil ini konsisten dengan penelitian yang dilakukan oleh Summer dan Sweeney (1998), Suyanto (2006), Skousen et al., (2009), Fimanaya (2014) yang menyatakan perubahan auditor tidak secara signifikan mempengaruhi kemungkinan kecurangan pelaporan keuangan. Sementara hasil penelitian yang berbeda ditunjukkan dalam hasil penelitian yang dilakukan oleh Lou dan Wang (2009) dan Rachmawati (2014) yang menyatakan bahwa pergantian auditor berpengaruh terhadap pelaporan keuangan yang curang. Lou dan Wang (2009) menyatakan bahwa perusahaan dapat menggantikan auditor untuk mengurangi kemungkinan mendeteksi laporan keuangan yang curang oleh auditor. Adanya perubahan auditor menunjukkan bahwa kegagalan audit meningkat dan menunjukkan bahwa telah 
terjadi kecurangan dalam perusahaan yang diketahui oleh auditor sebelumnya. Chen dan Elder (2007) menyatakan bahwa perusahaan dengan pergantian auditor yang lebih umum, cenderung lebih terkait dengan laporan keuangan yang curang.

\section{H4 ditolak sehingga dapat dikatakan bahwa DCHANGE tidak berpengaruh pada Manajemen Pendapatan.}

Ini bisa terjadi jika perusahaan membuat perubahan direksi untuk mendeteksi manajemen laba yang telah dilakukan oleh direksi sebelumnya. Direksi baru perlu waktu untuk beradaptasi dengan informasi keuangan perusahaan. Jadi, dengan pergantian direksi maka akan sedikit sulit untuk mendeteksi manajemen laba yang dilakukan oleh direksi sebelumnya. Hasil penelitian ini konsisten dengan penelitian yang dilakukan oleh Sihombing dan Rahardjo (2014) dan Tessa dan Harto (2016) yang menunjukkan hasil bahwa perubahan direksi tidak mempengaruhi laporan keuangan yang curang.

H5 ditolak sehingga dapat dikatakan bahwa CEO tidak berpengaruh pada Manajemen Pendapatan.

Hal ini disebabkan oleh fakta bahwa dari semua perusahaan yang menjadi sampel penelitian, tidak banyak perusahaan yang menampilkan foto CEO dalam laporan tahunan sehingga jumlah foto CEO yang ditampilkan tidak dapat digunakan sebagai faktor dalam indikasi manajemen laba. Penelitian ini bertentangan dengan penelitian Tessa dan Harto (2016) yang menyatakan bahwa jumlah gambar CEO mempengaruhi penipuan laporan keuangan.

H7 diterima, sehingga dapat dikatakan sebagian EM berpengaruh negatif terhadap Laporan Keuangan Fraudulent.

Tindakan manajemen laba adalah dasar untuk laporan keuangan yang curang atau laporan keuangan yang curang. Cornett et. al (dalam Ujiyantho dan Pramuka, 2007) mengatakan bahwa tindakan manajemen laba untuk mendapatkan rencana bonus telah menyebabkan sejumlah kasus skandal pelaporan akuntansi yang dikenal luas. Rezaee (2002) berpendapat bahwa laporan keuangan yang curang sering didahului oleh salah saji atau manajemen laba dari laporan keuangan triwulanan yang dianggap tidak material tetapi pada akhirnya tumbuh menjadi skandal penipuan besar-besaran dan menghasilkan laporan keuangan yang secara material menyesatkan.

\section{H8a ditolak sehingga dapat dikatakan bahwa ROA tidak berpengaruh pada Laporan Keuangan Penipuan.}

Return on Assets (ROA) adalah ukuran kinerja operasi perusahaan yang digunakan untuk mengidentifikasi seberapa efisien aset yang dimiliki (Skousen, et., Al, 2009: 62). Ketidakmampuan ROA atau target keuangan dalam mendeteksi laporan keuangan yang curang, adalah karena ROA tidak dapat membedakan perusahaan penipuan dan nonpenipuan. Seperti yang terlihat dalam penelitian Sukirman dan Sari (2013) dan Skousen, et., Al (2009), di mana ROA tidak dapat membedakan perusahaan penipuan dan non-penipuan. Tiffani dan Marfuah (2015: 122) mengemukakan bahwa non-pengaruh ROA pada penipuan laporan keuangan juga disebabkan oleh manajer dengan asumsi bahwa ukuran target ROA masih dianggap wajar dan dapat dicapai. Sehingga target keuangan tidak memicu kecurangan laporan keuangan oleh manajemen. Hasil ini mendukung penelitian yang dilakukan oleh Tessa dan Harto (2016); Dalnial, et., Al (2014); Sukirman dan Sari (2013); dan Skousen, et., al (2009) yang menunjukkan bahwa target keuangan yang ditunjukkan oleh proksi ROA tidak memiliki pengaruh yang signifikan terhadap laporan keuangan yang curang, atau dengan kata lain tidak memiliki kemampuan untuk mendeteksi laporan keuangan yang curang. Namun, hasil ini tidak mendukung penelitian yang dilakukan oleh Huang, et., Al (2016); Yesiariani dan Rahayu (2016); Lin, et., Al (2015); Firmanaya dan Syafruddin (2014); dan Suyanto (2009), di mana target keuangan memiliki pengaruh signifikan terhadap laporan keuangan yang curang.

H8b diterima sehingga dapat dikatakan bahwa DER memiliki efek negatif terhadap Laporan Keuangan Penipuan. 
Dapat disimpulkan bahwa ukuran nilai tekanan eksternal tidak akan mempengaruhi potensi laporan keuangan penipuan. Ini dimungkinkan karena dalam perusahaan pendanaan dalam bentuk utang, sebagian besar pihak ketiga memiliki banyak risiko, misalnya ketika perusahaan tidak mampu melunasi utangnya. Selain itu, perusahaan yang memiliki leverage tinggi berarti perusahaan memiliki hutang yang besar dan risiko kredit yang tinggi. Oleh karena itu, perusahaan cenderung mencari modal tambahan selain dengan meningkatkan hutang dengan menerbitkan kembali saham (Annisya et al., 2016). Hasil penelitian ini mendukung hasil penelitian yang dilakukan oleh Sihombing dan Raharjo (2014), Tiffani dan Marfuah (2015), dan Tessa dan Harto (2017) yang menyatakan bahwa tekanan eksternal memiliki pengaruh positif yang signifikan terhadap laporan keuangan yang curang. Begitu juga dengan hasil penelitian Skousen et. Al. (2009) yang menyatakan bahwa tekanan eksternal berpengaruh pada laporan keuangan yang curang. Tetapi hasil penelitian ini bertentangan dengan penelitian yang dilakukan oleh Annisya et. Al. (2016), Pardosi (2015) dan Ulfah et. Al. (2017) menyatakan bahwa tekanan eksternal tidak mempengaruhi laporan keuangan yang curang.

\section{H9 ditolak sehingga dapat dikatakan bahwa RKI tidak berpengaruh terhadap Laporan Keuangan Penipuan.}

Ini berarti bahwa ketidakefektifan pengawasan tidak memiliki efek positif yang signifikan terhadap laporan keuangan yang curang, sehingga hipotesis 4 tidak didukung. Dapat disimpulkan bahwa besarnya nilai ketidakefektifan pengawasan, tidak akan mempengaruhi potensi laporan keuangan yang curang. Dari hasil pengujian dapat dinyatakan bahwa banyak atau setidaknya anggota komisaris independen tidak dapat mencegah laporan keuangan yang curang. Ini mungkin terjadi karena kehadiran komisaris independen di perusahaan hanya persyaratan peraturan dalam memenuhi tata kelola perusahaan yang baik atau formalitas sementara dalam praktiknya mereka masih dapat dipengaruhi atau diintervensi oleh perusahaan (Kurnia \& Anis, 2017). Hasil penelitian ini tidak mendukung penelitian yang dilakukan oleh Putriasih et.al., (2016), yang menyatakan bahwa pemantauan yang tidak efektif dapat memprediksi terjadinya laporan keuangan yang curang. Namun, hasil penelitian ini mendukung hasil penelitian yang dilakukan oleh Sihombing dan Raharja (2014), Tessa dan Harto (2016), dan Kurnia dan Anis (2017) yang menyimpulkan bahwa pemantauan yang tidak efektif tidak mempengaruhi penipuan laporan keuangan.

\section{H10 diterima sehingga dapat dikatakan bahwa CPA memiliki efek positif terhadap Laporan Keuangan Penipuan.}

Perusahaan membuat perubahan auditor untuk mencakup deteksi laporan keuangan yang curang oleh auditor lama. Dengan demikian, dengan pergantian auditor, kemungkinan untuk menutupi laporan keuangan yang curang. Pergantian auditor dapat disebut sebagai kehilangan jejak bagi perusahaan tempat penipuan dapat ditemukan oleh auditor lama. Namun berdasarkan hasil penelitian, perubahan auditor membuat pembenaran atas tindakan yang diambil (rasionalisasi) yang dapat digunakan sebagai alasan bagi pelaku untuk melakukan kecurangan. Selain itu, ada perubahan auditor lama menjadi auditor. Hanya dapat disimpulkan bahwa auditor pengganti memiliki pengalaman dalam audit. Hasil penelitian ini bertentangan dengan penelitian Sihombing dan Rahardjo (2014) dan Tessa dan Harto (2016) yang menyatakan bahwa perubahan auditor tidak mempengaruhi laporan keuangan yang curang.

\section{H11 ditolak sehingga dapat dikatakan bahwa DCHANGE tidak berpengaruh pada Laporan Keuangan Penipuan.}

Ini mungkin terjadi karena dewan direksi di perusahaan hanya merupakan persyaratan peraturan dalam memenuhi tata kelola perusahaan yang baik dan kurang transparan. Selain itu, adalah mungkin bagi perusahaan untuk puas dengan kinerja dewan direksi dan tidak ada masalah dari pemegang saham yang berusaha untuk menggantikan dewan direksi sebelumnya. Sedangkan jika ada perubahan direksi, diharapkan mereka akan lebih kompeten dan memiliki inovasi yang dapat meningkatkan kinerja perusahaan. Dari hasil 
penelitian ini dapat disimpulkan bahwa semakin besar nilai perubahan direksi, tidak akan mempengaruhi potensi laporan keuangan yang curang. Hasil penelitian ini tidak mendukung hasil penelitian yang dilakukan oleh Pardosi (2015) dan Putriasih et. Al. (2016) yang menyatakan bahwa perubahan direksi berdampak pada laporan keuangan yang curang. Namun, hasil penelitian ini sejalan dengan penelitian yang dilakukan oleh Tessa dan Harto (2016), Kurnia dan Anis (2017), dan Ulfah et. Al. (2017) yang menyatakan bahwa perubahan direksi tidak mempengaruhi pelaporan keuangan yang curang.

\section{H12 diterima sehingga dapat dikatakan bahwa CEO memiliki efek negatif terhadap Laporan Keuangan Fraudulent.}

Ini mungkin terjadi karena penampilan foto CEO dalam laporan tahunan untuk menampilkan statusnya setiap tahun begitu penuh perhatian sebagai media untuk menampilkan statusnya. Kemunculan di media elektronik juga merupakan media untuk menghadirkan diri kepada publik sehingga masyarakat mengetahui status mereka sebagai CEO. Berdasarkan penelitian tersebut sesuai dengan hasil penelitian Tessa dan Harto (2016), Siddiq et. Al. (2017), dan Arrisandi dan Verawaty (2017) yang menyatakan bahwa seringnya gambar-gambar CEO memiliki efek positif yang signifikan dalam mendeteksi pelaporan keuangan yang curang. Namun, hasil penelitian ini tidak mendukung penelitian yang dilakukan oleh Kurnia dan Anis (2017) dan Ulfah et. Al. (2017) yang menunjukkan bahwa seringnya gambar-gambar CEO tidak berpengaruh pada laporan keuangan yang curang.

\section{Pengujian intervensi}

Manajemen laba dalam penelitian ini berfungsi sebagai variabel intervening yang dapat memediasi antara variabel independen yaitu Tekanan, Peluang, Rasionalisasi, Kompetensi, Arogansi dan variabel dependen, Laporan Keuangan Fraudulent. Ini menjelaskan bahwa lima variabel independen jika digunakan bersama akan memengaruhi manajemen laba. Dengan tekanan tinggi, peluang tinggi, Rasionalisasi tinggi, kompetensi tinggi, dan arogansi tinggi akan membuat perusahaan melakukan manajemen laba berdasarkan rencana bonus untuk melakukan penipuan. Laporan keuangan penipuan sering dimulai dengan manajemen laba karena manajer mencoba mengatur laba sehingga dapat memaksimalkan bonus. Laporan keuangan penipuan triwulanan yang dianggap tidak material tetapi akhirnya tumbuh menjadi skandal penipuan besar-besaran dan menghasilkan laporan keuangan yang menyesatkan secara material.

\section{Temuan Penelitian}

DER Research secara konsisten memengaruhi manajemen laba dan laporan keuangan yang curang. mendapatkan perilaku manajemen meningkatkan keuntungan sementara DER adalah total hutang yang tinggi. Dengan total utang yang tinggi, bunga pajak juga tinggi. Dengan demikian bunga pajak akan mengurangi laba. Tindakan manajemen laba adalah dasar untuk laporan keuangan yang curang atau laporan keuangan yang curang. Tindakan manajemen laba untuk mendapatkan paket bonus telah menyebabkan sejumlah kasus skandal pelaporan akuntansi yang dikenal luas. Penipuan laporan keuangan sering didahului oleh salah saji atau manajemen laba dari laporan keuangan triwulanan yang dianggap tidak material tetapi akhirnya tumbuh menjadi skandal penipuan besar-besaran dan menghasilkan laporan keuangan yang menyesatkan secara material.

\section{Simpulan}

Berdasarkan hasil analisis dan diskusi yang disajikan dalam bab sebelumnya, dapat disimpulkan sebagai berikut: bahwa ROA, DER, RKI memiliki efek positif pada manajemen laba. Sedangkan laba manajemen memiliki efek negatif pada laporan keuangan yang curang. DER dan CEO memiliki efek negatif pada laporan keuangan yang curang dan CPA memiliki efek positif pada laporan keuangan yang curang. Dapat disimpulkan bahwa Bonus plan berdasarkan Earning Management dalam penelitian ini berfungsi sebagai variabel intervening. Ini menjelaskan laporan keuangan yang curang yang seringkali dimulai dengan manajemen laba karena manajer mencoba mengatur laba untuk memaksimalkan bonus. Berdasarkan hasil pengujian dan kesimpulan 
yang telah dijelaskan sebelumnya, maka saran yang dapat disampaikan adalah: Penelitian selanjutnya dapat memilih sampel penelitian dengan berbagai sektor industri. Penelitian lebih lanjut, dapat menggunakan metode kualitatif atau kombinasi metode kuantitatif dan kualitatif. Karena, beberapa variabel yang terkandung dalam faktor risiko penipuan tidak dapat dijelaskan secara khusus oleh alat analisis metode kuantitatif. Studi selanjutnya dapat menggunakan pengukuran lain selain $\mathrm{F}$ Score sebagai ukuran laporan keuangan yang curang untuk memberikan keragaman dalam studi berikutnya. Penelitian selanjutnya dapat menggunakan variabel proksi lain untuk faktor risiko penipuan yang dapat lebih menjelaskan variabel dependen.

\section{Daftar Pustaka}

ACFE. 2014. Report to The Nation on Occupational Fraud And Abuse 2014 Global Fraud Study. Association of Certified Fraud Examiners, p. 1-80.

AICPA, SAS No. 99. 2002. Consideration of Fraud in a Financial Statement Audit, AICPA. New York.

Albrecht, W.S, and Chad Albrecht, 2012. Fraud Examination \& Prevention. Australia: Thomson, South-Western..

Aprilia. 2017. The Analysis of The Effect of Fraud Pentagon on Financial Statement Fraud Using Beneish Model in Companies Applying The Asean Corporate Governance Scorecard. Jurnal Akuntansi Riset, Vol 6, No. 1, p. 96-126.

Arrozi, Adhikara MF, 2011, Creative Accounting: Apakah Suatu Tindakan Ilegal?, Jurnal Akuntansi Akrual, Vol. 2 No. 2, pp. 109-135.

2012, Perilaku Creative Accounting dalam Perekayasaan Laporan Keuangan, Simposium Nasional Akuntansi dan Bisnis , Maret 2012, Universitas Widyatama.

2018, Pressure On Creative Accounting, International Conference
Research on Management Business (ICRMB), IFMA Universitas Islam Malang.

Arrozi, MF., Maslichah, Nur Diana, 2014, Qualitative characteristics of accounting information in the belief revisión of the users for the securities prospects in Indonesia Stock Exchange, Journal of Economics, Business, \& Accountancy Ventura, LPPM STIE Perbanas Surabaya, Vol. 17, No. 1, April.

2016, Mimetic Action Performed By Individual Investors At Indonesia Stock Exchange (IDX), SerialsjournalsInternational Journal Applied Business and Economic Research, Vol. 14 No. 6 (I), Juni 2016

2017, The Benefits of Accounting Information On The Intention of Stocks Selections In Indonesia Stock Exchange (IDX), The Indonesian Journal Of Accounting Research, 2017, 20, 1, January 2017, ISSN:2086-6887.

Beneish, Messod. 1999. The Detection of Earning Manipulation. Financial Analysis Journal. Vol 55, No. 5, p. 1-27.

Cressey, D. 1953. "The Internal Auditor as Fraud Buster". Managerial Auditing Journal. MCB University Press.

Dalnial, Hawariah, et al. 2014. Detecting Fraudulent Financial Reporting through Financial Statement Analysis. Journal of Advanced Management Science. Vol. 2, No. 1, p. 17-22.

Dechow, Patricia M., Weili Ge, Chad R. Larson, and Richard G Sloan. 2009. Predicting material accounting misstatements. Working Paper. University of California, Berkeley,

Fisher, Marilyn, dan Kenneth Rozensweigh. 1995. Attitudes of Students and Accounting Practicioners Concerning the Ethical Acceptability of Earnings Management. Journal of Business Ethics, Vol. 14, 
Marks, Jonathan. 2012. The Mind behind the Fraudsters Crime: Key Behavioral and Environmental Elements. Crowe Howarth LLP (Presentation).

Marliani, Mery dan Yulius Jogi, 2015, Pengaruh Persepsi Fraud Triangle Terhadap Pencurian Kas, Businmess Accounting Review, Vol. 3, No. 2.

Tessa G, Chynthia, dan Puji Harto. 2016. Fraudulent Financial Reporting: Pengujian Teori Fraud Pentagon pada sektor Keuangan dan Perbankan di Indonesia. Simposium Nasional Akuntansi XIX Lampung, p. 1-21.

Sihombing, Kennedy Samuel, dan Shiddiq Nur Rahardjo. 2014. Analisis Fraud Diamond dalam Mendeteksi Financial Statement Fraud: Studi Empiris pada Perusahaan Manufaktur yang Terdaftar di Bursa Efek Indonesia (BEI) Tahun 2010-2012. Diponegoro Journal of Accounting. Vol. 03, No. 02, p. 1-12.

Skousen, J.C., Wright, J.C., Smith Kevin, R. 2009, "Detecting and Predicting Financial Statement Fraud: The Effectiveness of The Fraud Triangle and SAS No. 99." Advances in Financial Economics, Vol. 13.

Harrington, Chyntia. 2005. Analysis ratios for Detecting Financial Statement Fraud. Fraud Magazine.

Howarth, Crowe Howarth, 2012, The Mind Behind The Fraudsters Crime: Key Behavioral and Environmental Element.

Lou, Young-I, dan Ming-Long Wang. 2009. Fraud Risk factor of The Fraud Triangle Assesing The Likelihood of Fraudulent Financial Reporting. Journal of Business \& Economics Research. Vol. 7, No. 2, p. 61-78.

Ratmono, Dwi, Yuvita Avrie, dan Agus Purwanto, 2014, Dapatkah Teori Fraud Triangle Menjelaskan Kecurangan dalam Laporan Keuangan?, Simposium Nasional Akuntansi 17 Mataram, 24-27 September 2014.

Ruankaew, T. 2013. The Fraud Factors. International Journal of Management and Administrative Sciences (IJMAS), 2 (2).

Tuanakotta, Theodorus M. 2013. Mendeteksi Manipulasi Laporan Keuangan. Jakarta: Salemba Empat.

Ujiyantho, Muh. Arief, dan Bambang Agus Pramuka. 2007. Mekanisme Corporate Governance, Manajemen Laba, dan Kinerja Keuangan (Studi pada Perusahaan Go Publik Sektor Manufaktur). Simposium Nasional Akuntansi X Unhas Makassar 26-28 Juli 2007, p. 1-26.

Scott, W. R., 2015.. Financial Accounting Theory, 6th edition. Toronto: Prentice Hall.

Sihombing, Kennedy Samuel, dan Shiddiq Nur Rahardjo. 2014. Analisis Fraud Diamond dalam Mendeteksi Financial Statement Fraud: Studi Empiris pada Perusahaan Manufaktur yang Terdaftar di Bursa Efek Indonesia (BEI) Tahun 2010-2012. Diponegoro Journal of Accounting. Vol. 03, No. 02, p. 1-12.

Watts and Zimmerman, 1986, Positive Accounting Theory, Prentice Hall.

Wolfe, David T, and Dana R. Hermanson. 2004. The Fraud Diamond: Considering The Four Element of Fraud. The CPA Journal, p. $38-42$ 